\title{
RESPONDING TO VIOLENCE: THE HASKAMOT OF BARCELONA AND THE JEWISH POLITICAL TRADITION
}

\author{
Mario Macías \\ (Institute of Law and Technology, Universitat Autònoma de Barcelona) \\ mario.macias@uab.cat
}

\begin{abstract}
The aim of this article is to present the Haskamot of Barcelona of 1354 in their political and legal context. These agreements were a response to the difficult situation faced by the Jews of the Crown of Aragon in the 14th c., when natural and human disasters threatened the survival of their communities. The target of this project was to assemble all the aljamas of the Crown in a supra-communal assembly of representatives. The drafters also wished to achieve a number a measures from the King and the Church improving the delicate situation of Catalan-Aragonese Jewry. These Haskamot, despite not succeeding in their objectives, are a perfect starting point for any research on the legal and jurisdictional relations between Christians and Jews.
\end{abstract}

Keywords: Jewish Political Thought, Medieval Catalonia, Jewish self-Government, $14^{\text {th }}$ century.

Acknowledgements: Project IEC PRO2018-S05. Models del dret i la filosofia política catalanes: semàntica de les doctrines juridicopolítiques del pactisme en les seves diferents fases [Models of Catalan political philosophy and law: Semantics of pactmodel driven political and legal doctrines at their different stages].

Disclosure statement: No potential conflict of interest was reported by the authors.

License: This work is under Attribution-NonCommercial-NoDerivs 3.0 Unported (CC BY-NC-ND 3.0)

http://creativecommons.org/licenses/by-nc-nd/3.0/

Suggested citation: Macías, M. (2019-2020). "Responding Violence: The Haskamot of Barcelona and the Jewish Political Tradition”, Journal of Catalan Intellectual History 12: 46-63 DOI: 10.2478/jocih-2019-0004 


\section{INTRODUCTION}

The purpose of this contribution is to present the agreements signed in Barcelona in 1354 by a number of delegates from some of the aljamas of the Crown of Aragon as a political and legal response to the rise of anti-Jewish hostility. In addition, this paper also aims to provide a preliminary approximation to the political and legal implications of the document. As will be observed, these haskamot intended to strengthen intercommunal cooperation, as well as to improve the management of the most transcendental aspects of their administration. Their final goal was the creation of a supra-communal institution, which would have become a groundbreaking construction in the Crown. The delegates thereby tried to overcome the endemic disunion and internal conflicts that weakened the aljamas and facilitated the Christian attacks, both legal and physical. However, these targets were impossible to achieve without the support of the monarchy and the Church.

The difficult context experienced during the reign of Peter III (IV in Aragon) the Ceremonious had deep negative effects on the Catalan society as a whole; however, the Jews, a repudiated minority, suffered its consequences with greater intensity. The dramatic introduction that opens the Haskamot of Barcelona and the subsequent demands attest to this situation. References to the assaults at the Jewish quartiers (especially in times of sickness and Christian celebrations), the abuse of authority by royal servants and the lack of self-government competences are frequent.

The historiographical interest of these agreements lays in their unintentional narrative richness. Though they were conceived as a cold and functional normative document, the Haskamot are, in fact, a neat portrait of Christian-Jewish relations in $14^{\text {th }} \mathrm{c}$. Crown of Aragon. Every single measure adopted shows an aspect of that intricate coexistence. They all are perfect departure points for any research in this regard. In addition, these haskamot allow appreciating the interaction of two legal systems in a complex reality. Jewish communities invested their efforts in keeping alive their laws and political traditions - a pretension more or less respected by CatalanAragonese monarchs - but they had to deal with the interferences of the external ruling powers. The interrelation of both systems in the Jewish sphere had an impact on some of their traditional conceptions about authority and self-government. This fact led to a certain hybridization of Jewish politics and public law, as well as to many — successful — attempts to Judaize the reception of Western influences, a reality denied by many scholars. The Agreements of Barcelona can open a door for the study of this phenomenon.

After presenting the content of the Haskamot of Barcelona, we will study their position in the Jewish Catalan legal tradition. One of the most striking aspects of the evolution of this tradition is the parallelism with the process of political and legal construction of Catalan statehood. The analysis of this aspect in these scarce pages would be an objective too ambitious, but we will try to summarily present the current scholarly debate about the independent birth of this tradition and its relation with European theories.

Ultimately, this paper is no more than a first approximation to the topics and ideas that are to be developed in my doctoral dissertation. 


\section{SOME NOTES ABOUT THE CONTEXT OF THE CATALAN JEWRY IN 1354}

As any other historical event, the Haskamot of Barcelona were a direct consequence of their particular context. Trying to summarize in a few lines the outlook of Judaism in the Crown of Aragon would be an impossible and futile task. The dialectic between popular hate and the attempts of governmental institutions to protect the Jewish subjects of the Crown was, as in the rest of Western Europe, constant. A huge number of excellent and extensive works has been written about anti-Jewish disorders, segregation, legal treatment and Christian apologetics. Therefore, we will limit ourselves to point two causes that had a direct impact on our topic: the Black Death, with all its aftermaths, and the financial situation of the Crown and its repercussion on Jewish communities.

These agreements were written barely six years after Black Death (summer of 1348), whose political, economic and spiritual consequences had important repercussions in the mentality of European societies. Even nowadays the Black Death still plays a dark role in the collective imagination. As all the regions affected by the disease, Catalonia experienced high mortality rates, though there is no agreement on the exact number of deceases. Indeed, the estimations proposed by the experts range from a 20\% (like Freedman 1991: 162) to a 70\% (Parrilla Valero 2019, for example) out of the $600,000^{1}$ inhabitants of Catalonia before the spreading of the pandemic ${ }^{2}$. In the city of Valencia, Peter III reported that in June "hi moriren tots jorns més de tres-centes persones" (Pere el Cerimoniós 1983: 1104) ${ }^{3}$. Obviously, Jewish communities were not an exception and they also suffered the ravages of the pandemic. In addition to this natural catastrophe, they had to deal with the outbreaks of anger among the Christian population, who needed to find a responsible for such a biblical plague.

Unlike other territories stricken by Black Death ${ }^{4}$, in Catalonia, as well as in the rest of the Crown of Aragon, no official document blaming the Jews for the propagation of the disease exists. That did not hamper popular explosions of violence against Jews, as the assault to the call (Jewish quartier) of Barcelona in that summer. Seemingly, Christian population did not consider that the Jews were the direct culprits of the plague (as poisoners or evil wizards); they rather thought that Jews were the main sinners that God wanted to punish (Nirenberg 1996: 239). Among all this chaos and devastation it is difficult to determine how many victims resulted from

\footnotetext{
${ }^{1}$ This is the estimation proposed by Postan and Miller (1987: 343). Unfortunately, the first large scale censuses on fireplaces (homes, fogatges in Catalan) in Catalonia were elaborated in the decades that followed to the pandemic. See Smith (1944), Ortí i Gost (1999) and Feliu, G. (1999).

${ }^{2}$ According to estimations exposed by Freedman (1991:162), mortality would have risen to $28.5 \%$ in La Seu d'Urgell and to $70 \%$ in the Plain of Vic. Antoni Pladevall (1962) studied the consequences of Black Death in the Plain of Vic, an inland Catalan region south the Pyrenees. He concluded that over two thirds of local population perished during the disease. The same rate is accepted by Bisson (1986: 165). Nirenberg (1996: 235) suggested that about a 36\% of Barcelonan population perished - that is, around 15.000 out of 42.000 inhabitants. Thomas Bisson (1986: 165) finally estimated that mortality ranged between the $25 \%$ and $35 \%$ for the entire Crown of Aragon. Nevertheless, estimations on mortality rates tend to be quite inexact since they can only rely on indirect sources, such as the number of last wills executions or the burial records of the parishes (Montoro 2018)

${ }^{3}$ Despite this number can appear overstated, d'Abadal (1987: 43) held that between 12.000 and 18.000 out of the 30.000 inhabitants of the city of Valencia were killed by Black Death, which lend credibility to the king's estimation of 9.000 deaths in June.

${ }^{4}$ Some examples of measures against Jews adopted by local noblemen and city councils in Central Europe are compiled in Horrox (1994: 208-211).
} 
the assaults, but some authors have pointed that they were enough to reduce drastically the Jewish demography in the Peninsula during generations ${ }^{5}$.

All the authors who have approached the text concur in the major role of the Black Death in triggering the agreements, especially for the necessity to prevent further popular outbreaks and forced conversions (Feliu and Riera 1987; Baer 2001, II: 24; Tartakoff 2012: 63, f.n. 4). However, despite the dramatic impact of Black Death and its aftermath on Jewish communities, there are no direct mentions to the pandemic in the Agreements. The only allusion to diseases in the text comes from their relation with the anti-Jewish disorders. Despite the lack of references, and albeit it would be nearly impossible to calculate the real impact of Black Death on this political decision, it is highly probable that such a horrible, traumatic, and transcendent fact (to which we should add the economic consequences and the explosions of violence ${ }^{6}$ ) had a direct influence on the planning of a project of that sort.

In addition to the impact that the Black Death had on the whole Catalan society, as well as to the rising legal and popular anti-Judaism, we should also pay attention to the financial situation of the Crown, particularly in Catalonia. The reign of Peter the Ceremonious was tumultuous in many aspects, both political and natural, which had a negative effect on the royal treasury. Leaving aside other factors that could have contributed to create this difficult economic context, the concatenation of wars in which the Crown of Aragon was involved played a major role. During his fifty years reign, King Peter had to deal with an endless number of conflicts. Some of them were internal, aroused by revolted noblemen (War of the Union, 1347-1348); in some others, the Crown had to fight against its neighbors in the Peninsula (perhaps the most important was the war against Castile, from 1356 to 1369) and others were provoked by power struggles in the Mediterranean, like the Sardinian revolts, the conquest of the Crown of Mallorca and the conflicts with Genoa. The weight of the military expenses was excessive and atrocious for royal economy (Bisson 1986: 107-121; AAVV 1991) and the king was pushed to frequently summon the Corts (saving distances, the Catalan Parliament) to defray his armies ${ }^{7}$. This led to the prorogation or endorsement of taxes and contributions.

Thus, for example, the sessions of the Corts held during the ten previous years to the writing of the Haskamot (between 1344 and 1354) evince the evolution of fiscal pressure: In the Corts held in Barcelona on March 1344, the donation of 70.000 pounds was approved to be collected from royal municipalities in order to finance the campaign against the Kingdom of Mallorca in the Roussillon; in the Corts held in Perpignan (November 1350), in Vilafranca del Penedès (march 1353) and in Barcelona (April 1353), it the direct collection of 170.000 bronze pounds was endorsed, as well as the approval of new taxes on trade goods and the prorogation of some

\footnotetext{
${ }^{5}$ Cohen $\operatorname{Jr}$ (2007: 31). In a wider perspective, the number of Jews in the Peninsula would have decreased from 900.000 at the end of XIII c. to 250.000 in 1410 due to violence, natural disasters and forced conversions. Also Baron ([1942] 1976: 16).

${ }^{6}$ Mosse Natan, one of the drafters of the agreements, is a good example: during the riots, his house was burned down and all his debt instruments were destroyed by the assailants. He stayed broke for the rest of his life. His brother Salomon was probably murdered in the attacks. Archivo de la Corona de Aragón (ACA), registros (reg.). 658, f. 178 v-179r [in Muntané i Santiveri (2006)]. Also, Alsin and Feliu, E (1995); and Muntané i Santiveri (2012).

Other instruments, like fiscal allocations to third parties and the alienation of the royal lands and jurisdictions were also frequently used. In fact, these practices led to a patrimonial crisis that the monarchy did not overcome until the $15^{\text {th }}$ c. See, Ferrer i Mallol (1970-1971).
} 
others, to defray the war in Sardinia against Genoa and the local rebels. Even in the previous month to the negotiation of the Agreements, a new imposition of 150.000 pounds was agreed upon (Sánchez Martínez and Ortí Gost 1997: 81-156).

These sums are just indicative because the Corts did not have authority to tax the Jews ${ }^{8}$, who were a royal property. However, fiscal pressure on the aljamas always tended to be stronger. Unlike the Christian subjects, who had the Corts to force the king to negotiate any new fiscal imposition, the Jews could be discretionally compelled to pay new taxes. Thus, when the king needed funds, the Jews were the first resort. Although we do not have any document detailing the parallel fiscal pressure on the aljamas, we have noticed the imposition of special taxes to support the war against Granada ${ }^{9}$ and the Saracens ${ }^{10}$ or even the king's marriage ${ }^{11}$.

Fiscal pressure has a leading presence in several demands of the Haskamot of Barcelona. As it will be observed later, more than the onerous burden of the new taxes (that was supported by all the Catalans), the real problem for Jewish communities was the excessive and unmerciful use of violence by tax collectors. Additionally, the high taxes had impoverished drastically not few aljamas $^{12}$. The objective of the Haskamot on fiscal issues was the suppression of these practices.

\section{THE CONTENTS OF THE HASKAMOT OF BARCELONA}

The Agreements of Barcelona are usually classified as taqqanot (תקנות; taqqanah in singular, תקנה (ת) The legal instruments are often described, especially those produced in the Middle Ages, as the communal ordinances of Jewish communities. Nevertheless, in this paper we have opted for the use of the term Haskamot (הסכמות; haskamah in singular, הסכמה), which literally means agreement. The difference between both legal categories is subtle and almost inexistent. Indeed, in the Catalan tradition both terms were often used as synonymous. However, we consider that the word haskamah is more suitable for a range of agreements enacted out of the usual legal procedures.

The elemental function of taqqanot and haskamot was supposed to be the development, adaptation and implementation of the Halakha, through a hermeneutical and realistic reinterpretation of the religious precepts to make them suitable for the daily management of the communities as socio-political entities (Dorff and Rosett 1988: 402-407). Nonetheless, they accomplished wider regulatory roles. The importance of tradition and the presence of a primal and unalterable legal framework (Torah) caused that most of the contents of the taqqanot and haskamot, just like the Cristian legal codes, were compilations of customs understood according religious law ${ }^{13}$. Louis Finkelstein compiled and translated some remarkable examples of medieval taqqanot in his classical book Jewish Self-Government in the Middle Ages (Finkelstein 1924).

\footnotetext{
${ }^{8}$ ACA, reg. 257, f. 44v, quoted and commented in Assis (1996-1997: 332).

${ }^{9}$ ACA, Cartas Reales, Alfonso III, c. 10, n 1343 (10 November 1330) [in Assis, Mañé and Escribà (1993: doc. 660)].

${ }^{10}$ ACA, Cartas Reales, Pedro III, c. 12, n 1561 (14 July 1340) [Assis, Mañé and Escribà (1993: doc. 935)].

${ }_{11}$ ACA, Cartas Reales, Pedro III, c. 23, n 3159 (23 October 1347) [Assis, Mañé and Escribà (1993: doc. 1074)].

12 ACA, Cartas Reales, Pedro III, c. 13, n 1718 (19 March 1343), c. 23, n 3196 (7 May 1347) and c. 23 , n 3193 (16 May 1347) [Assis, Mañé and Escribà (1993: docs. 1015, 1071 and 1072, respectively)]. Also: Assis (1997).

${ }^{13}$ Shetreet and Homolka (2017: 14-15). The authors point that until the $16^{\text {th }} \mathrm{c}$. the rigidity of Jewish legal sources hampered the production of original and modern legislation. However, it is worthy to note that the Haskamot of Barcelona differed in many ways with this general principle.
} 
Despite the particular context of the Jewish communities in the medieval world (scattered, segregated from their environment and at the mercy of popular violence) which led to the proliferation of these codes, the taqqanot were not a genuine invention of Medieval European Judaism. Actually, their historical origins might be found in the early antiquity, approximately in the times of the Second Temple ( \pm 530 B.C to 70 A.D). Local nucleuses, especially those far from urban centers, were regulated by semi-autonomous assemblies composed by the elders and other dignitaries of the community. These leaders were in charge of interpreting properly religious laws in order to implement them adequately for the political and economic administration of those settlements (Shapira 2014: 269-272). With the diaspora and its habitual marginalization in Christian territories, Judaism faced an inevitable process of governmental, judicial and religious decentralization that required from a greatest and more dynamic legal production (Elon 1993: 41).

The Haskamot of Barcelona were written in September 1354, in one of the most turbulent periods of the turbulent reign of Peter III the Ceremonious. Their authors were three wealthy oligarchs from the aljamas of Barcelona, Tàrrega and Valencia: Crescas Solomon, Judah Eleazar and Moses Nathan. Their main objective was to reach a further political union of the aljamas through the creation of a supra-communal assembly and the adoption of common policies. The elemental task entrusted to the delegates was the achievement of legal concessions from Christian authorities improving the competences and protection of the aljamas. They wanted to appear as a single entity, with a single voice, before the king and the Church. To succeed in their goals, the elected delegates would have been provided with full powers of negotiation and decision. The Agreements would have been binding for the whole Jewry of the Crown, once they had been sanctioned by the king.

Finkelstein asserted that there was a second text containing specific measures related to the internal management of the communities - though he did not provide any evidence or argument supporting this theory. In his opinion, this second part of the Haskamot would have been similar to other compilations carried by other communities culturally similar, like the Taqqanot of Toledo of 1432 and those agreed in Italy between 1416 and 1418 (Finkelstein 1924: 102).

As for the editions and studies on the text, the Galician maskil scholar Joshua (Osias) Herschel Schorr published the very first edition and comment on the text of the Agreements in the first number of the journal He-Halutz (The Pioneer) in 1852 (Schorr 1852) ${ }^{14}$ - an annual publication managed by Schorr and distributed among Haskalah circles in Centre Europe between 18521859. Two more editions of the manuscript were published during the first half of the twentieth century: One by Fritz [Yitzhak] Baer in his archival compendium Die Juden im Christlichen Spanien (1929: 348-359) and the other by Louis Finkelstein in his book Jewish self-Government in the Middle Ages (1924: 328-335). In his books Studien zur Geschichte der Juden im Königreich Aragonien (1965: 123-126) and History of the Jews in Christian Spain (2001: 24-28), Baer devoted a number of pages to address the general features of the document and the drafters' biography, although he did not conduct a deep analysis and did not untapped the legal dimensions and possibilities of the document.

"דברי הברית:אשר באו בו איזה קהלות ספרד בשנת הייא קטייו (1354)עם הקדמה והדות. 14

[ "On the Agreement that Came from the Communities of Spain in the year 1354, with an Introduction and Testimony ] 
Two exhaustive works on the Haskamot of 1354 appeared later. The first one was copublished by the Catalan researchers Eduard Feliu and Jaume Riera in the journal Calls, in 1987. The article — "Els acords de Barcelona de 1354" —was composed by Feliu's full Catalan translation of the agreements and by a fifteen pages essay written by Riera (Feliu and Riera 1987). It also included a short documentary annex related to the outputs of the proposals. Finally Bert Pieters (2006) published a small book in Flemish titled De Akkorden van Barcelona (1354). Historische en Kritische analyse. However, less than a third of the book is really devoted to the agreements, while the rest focuses on the general context of the Catalan Jewry. The greatest virtue of this work is the edition of the text-including a facsimile version of the original manuscript- and the linguistic analysis.

It is possible to find short and superficial—sometimes almost anecdotal-references to the Agreements of 1354 in a nearly endless list of works, especially thanks to the influence of Finkelstein's Jewish self-Government.

The Haskamot start with a poetical preamble in which the author mourns for the disgraces suffered by the people of Israel during their exile. The long and tortuous diaspora, the prosecutions and massacres perpetrated by the Christians, the forced conversions and the resentment of many converts against their former coreligionists are some of the calamities mentioned in this elegy. The author points out that the progressive deterioration of the position of the aljamas is historically evident. This current situation, as the verses claim, has been emphasized by the internal disputes and the lack of unity. Louis Finkelstein did not translate this preamble because he considered that it was impossible (Finkelstein 1924: 336). For his part, Eduard Feliu, in the prologue of his integral translation (including the preamble), attributed the difficulties of the Hebrew text to the paraphrases of the biblical text and to the lack of literary skills of the author (Feliu and Riera 1987: 146). This last assertion contradicts Baer's hypothesis, who attributed the prolegomena to Nissim b. Reuben of Girona, one of the most prominent scholars of the period (Baer 2001, II: 26). Perhaps it was written by one of the drafters, Mossé Natan, who was himself a poet.

The preamble is followed by the proposals. According to the general nature of the petitions, they can be classified in two basic groups. On one hand, the measures that the delegates expected to achieve from the king and the Pope. On the other hand, those related to internal organization. The drafters' objective was that the king would sanction the agreement, accept the unitary representation of the aljamas and, if it was the case, he would act as mediator before the Pope. In fact, the text, after recalling once again the suffering of the people of Israel, starts with a list of pompous praises to the goodwill of the king and his ancestors, as well as to the Pope, who is named King of Nations (or of the "gentiles", depending on the translation: "מלך הגוים"). On the other hand, there are a number of provisions related to the legal regime (duties and responsibilities) of the delegates.

The first petitions are addressed to the Pope. The authors of the text complain about the attacks and assaults to the calls every time that epidemics and hunger spread (this is the only reference to diseases). According to the text, it was not unusual that occasional miracles or divine manifestations were interpreted as God's signs to go against the Jews. In order to avoid these episodes, they ask the pontifex to consider heretics these interpretations, as well as to discredit the priers who used to predicate in that way. Going beyond, they demand the prohibition of anti- 
Jewish aggressions under penalty of excommunication $\left(\Phi\left[2^{15}\right)\right.$. Although targeting the use of excommunication to protect the Jews was an ambitious target, it was one of the few points that had a relative success, as it will be shown later. Another proposal in order to prevent the assaults was to declare sinful the construction of towers and embankments surrounding the calls because they were usually utilized to attack the communities $(\mathbb{\Phi}[3)$.

The other demands to the Church are all related to the inquisitorial processes. Firstly, they requested that the inquisition must refrain from bringing charges against any Jew who held opinions not shared by Christianism (II4). The writers begged for restricting inquisitorial prosecutions to those blasphemies and heresies common to both creeds, like denying the divine origin of the Torah; only Jewish courts should be in charge of the processes referring internal religious issues. The prosecution of Jews accused of blasphemy toward Catholic dogma was a usual practice along Western Christendom since the $13^{\text {th }} \mathrm{c}$. and soon became widely popular in Catalonia, especially after the Disputation of Barcelona in $1263^{16}$.

They also asked for the acknowledgment of a number of due process rights, such as the right of the defendant to know the content of the indictment and to have the assistance and representation of lawyers and legal experts (II4). The main target of that last proposal was to avoid judicial processes motivated by false accusations. In order to achieve all these concessions from the Church, the Haskamot foresee the possibility of electing more delegates to act as representatives of the aljamas in front of the Ecclesiastical authorities.

Most of the requests to the king pursued political and administrative objectives, like the improvement of self-government competences, the reduction of fiscal pressure and the adoption of some measures aiming to guarantee the viability of the project. Regarding the protection of the physical integrity of the communities, the delegates just expected from the king to control the abuses of power exerted by his officials (II17, for example). It seems that the writers of the Agreements were more worried about achieving the protection of the Church rather than the king's. That might not be surprising. Officially, the communities already enjoyed royal protection, and monarchs used to be compliant with this duty as far as possible. Street preachers were the real instigators and the intellectual authors of the attacks (McMichael and Myers 2004: 173176). The delegates requested the king to deprive from protection and employment anyone who has killed a Jew or incited riots (II9).

In the fiscal domain, and in addition to the cease of brutality from tax collectors (II13), the delegates aimed to be exempted from financing the protector aliamorum iudeorum terre nostre, an institution created some years before the Black Death (Riera 2018) to protect the aljamas from possible attacks (I15). The viscount of Illa was appointed for the charge, but he died little after. He was succeeded by the Infant Joan - the future Joan I-when he was barely three years old. The drafters considered that the institution should have been abolished after the death of the viscount. In the same way, they ask for the end of their legal duties to provide the collectors with ac-

\footnotetext{
${ }^{15}$ The proposals are identified according to the numeration of the paragraphs proposed in Baer (1929).

${ }^{16}$ Grayzel (1933: 29-33). For his part, Robert Chazan (2006: 44-51) holds that considering "blasphemy" all the Jewish beliefs contrary to Christianism was one of the main of causes of the progressive abandonment of the Agustinian thesis related to tolerance towards Jews. In the case of Catalonia after 1263, the fight against the infidel used to combine the legal prosecutions with an active missionizing activity, mainly carried by the Dominicans. See, for example: Cohen (1983: 168-169).
} 
commodation and to pay part of their salaries (II4 and I18). The delegates also inform the king that many aljamas have created a common fund to prevent the economic consequences of future riots ( $(\llbracket 9)$.

On the measures aiming to improve communal self-government, a number of them show the delegates' special interest in expanding the judicial capabilities of the aljamas. In fact, the paragraphs about the inquisitorial processes advanced some aspects of the delegates' intention to improve the Jewish court system. The writers claimed for the effective implementation of the judicial autonomy granted by several royal privileges (\$19). Royal attorneys would have to be deprived from their faculties to commence public processes if there is not a previous denounce (I20). The objective of these measures, as it is indicated in the text, was to promote unity and to purge the aljamas of unwanted individuals, such as the informers, who were supposed to be the greatest danger for the stability and safeguard of the communities (II8).

The elemental action tools to guarantee the implementation of these reforms were the Herem and fines, as in almost all medieval taqqanot (Neuman 1944, I: 50). The herem (חרם) could be considered as the Jewish equivalent to the Christian excommunication, "a ban imposed on an individual to separate him from the other members of the community (...) a method of maintaining communal cohesion and authority" (Jacobs 2015: 234). Due to the limitations of the judiciaries in European Jewish communities and the difficulties to inforce penalties, the Herem became the basic legal punishment in any community. Actually, there is not a unique and univocal definition of the concept. The wide and diverse casuistry in which this institution is mentioned in the Torah (Lyons 2010: 25-34) and the decentralization of Jewish governments during the Middle Ages led to a rich and varied typology of Herems ${ }^{17}$. However, the definition we have provided reflexes accurately the nature of this penalty in the Agreements of Barcelona. When the offense was mild and the repudiation was short, the punishment was called niddui (נידוי), which is also mentioned in the Haskamot. These punishments were to be imposed on those who contravened the Haskamot or the decisions of the delegates (II24 and I[32), as well as on those communities that did not pay their contributions to the common treasury ( $(22)$.

The authors of the Haskamot were completely aware of the fact that the mere authorization of the king would not be enough to ensure the success of the project. A closer cooperation with royal institutions was necessary. Several proposals appear to pursue this ultimate goal. First, the drafters aimed to obtain the right to participate in the Corts (II1). They also aimed for that the king to use his power to collect the contributions of the aljamas which had signed the Haskamot and from those which had not signed them but benefited from the achievement of new general measures (I23). At the same time, they ask the king for ensuring the enforcement of the herems enacted against individuals (II26).

The last parts of the document deal with the legal regime of the delegates, including the method of election ( $\Phi[28)$, the budget ( $\Phi[33)$ and their functions. On that point, the text becomes greyer and more functional; there is an abandonment of the demonstrations of pain and passion that, in some occasions, we can observe in the petitions. In contrast, these regulations are succinct

\footnotetext{
17 Thus, for example, the notion of herem ha-yishub (חרם הישוב), a preventive ban on foreigners very popular among East European Jews, was unknown in the Iberian Peninsula; see, Rabinowitz (1938).
} 
and quite superficial; the authors do not seem to aim to develop profusely the vicissitudes of the charge. Perhaps, they supposed that they would be able to solve the problems on the go or maybe they wanted to postpose the debate. Nevertheless, and as it has been pointed by Jaume Riera (Feliu and Riera 1987), the Agreements cannot be considered a democratic initiative in the current meaning of the term. The authors were three ambitious plutocrats with important commercial and political interests. The lack of response from many of the aljamas - especially from the Kingdom of Aragon (I29) — and the attempts to achieve more judicial competences prove that the quest for unity was not as unanimously wished as it pretends to be in the text. The material success of the project - notwithstanding the multiple benefits that it would have produced for the aljamaswould have also conferred a nearly absolute power to these men and would have guaranteed their political supremacy.

The project was a failure. The delegates only reached partial successes, but they could not accomplish the creation of a confederation of aljamas. Perhaps, their goals were too ambitious. They just got some specific concessions from the king and the pope, and none of them increased the autonomy of the aljamas. These concessions were granted slowly, and some of them required from prolonged and costly embassies in the papal court of Avignon (Baer 2001, II: 27). The conserved bulls and letters were compiled by Jaume Riera in his already cited work, "Guia per una lectura comprensiva dels acords". Thus, the delegates achieved (with the mediation of the king) a papal bull condemning the attacks and false accusations against Jews. They also achieved a number of edicts forbidding the extortions by royal officials.

Although these agreements failed, mostly due to their inability to reach unity between the aljamas, they were not the only attempt in that sense during the XIV c. Despite no supracommunal organization existed in the Crown of Aragon, a royal decree allowed, some decades later, the instauration of a supreme judge for all the aljamas. This institution had its greatest peak under the leadership of the prolific scholar Hasdai Crescas (1340-1410) (Ray 2012: 314).

\section{JEWISH TRADITION, EUROPEAN CONTEXT}

Despite the failure of the project of the Agreements of 1354, its study does not lack interest. If the drafters had reached their targets, they would have revolutionized the organization of the CatalanAragonese communities. Their first remarkable element is, without a shadow of a doubt, the effort made to overcome the notion of community as a single and self-governed entity. They aspirated to create a confederation almost comparable to which nowadays we would call international integration. Contrarily to the traditional political conceptions, the decisions taken by the delegates could have had effects on the rest of communities. Secondly, the traditional Jewish model of representation was taken a step further in order to create a supra-communal organization in which the delegates were more than representatives of their aljamas, but representatives of all the Jews in the Crown. Thirdly, the achievement of this goal would have required from a harmonization of the criteria of interpretation of the Halakha and communal norms, contributing to uniform legal hermeneutics. Disagreements on the Halakhatic interpretations could have been a source of conflicts between communities, as well as a danger for the project. 
The fourteenth century ushered the decadence of Catalan-Aragonese Jewry. Forty years after the outburst of violence during the Black Death, the chain of assaults occurred in 1391 implied the disappearance of a great amount of aljamas, including the huge and important community of Barcelona. Albeit it is usually assumed that the expulsion in 1492 was the abrupt end of Iberian Jewry, it was just the definitive endpoint for a social group which had languished after a long agony. Perhaps, the success of the project would have contributed to bypass some of those traumatic events. The result would have probably been the same; but the path could have been less bloody and traumatic.

Aside from the ambition of the project and its hypothetical outputs, its interest lays on the information it can bring to light. Haskamot and taqqanot ha-qahal were enacted in order to offer a legal response to the problems and organizational necessities in a particular time and place. For historians, they are static portraits of the concerns and political inclinations of the communities. In the case of the Agreements of 1354, they do not provide any input about intra-communal daily life, but their value as historical document is incalculable. Each proposal is a perfect starting point for research on the legal relationship between Christian/Royal and Jewish institutions. Despite many works on the Agreements have been published, none of them have addressed the text from the perspective of legal historiography-considering that these haskamot are a legal document, it is an unforgivable mistake. In consequence, many elements remain untapped, especially in their relationship with the devolvement of Jewish legal and political traditions.

Throughout the twentieth century, Jewish historiography has appeared to be interested in the development of the legal and political tradition in European communities, especially on the evolution of the use of majority rule in decision-making. A minority part of the authors has considered that the political evolution of Medieval Judaism was a consequence of the influence exerted by Roman law, as well as by the coetaneous theories that were blossoming within the European States (Baer 1989), which has been harshly criticized by a wide range of scholars (Agus 1952; Elazar 1997; Shapira 2014, for example). Paralleling Judaism, Christian religious hermeneutics and juridical interpretation enabled the development of a range of theories about civil participation, which became the roots of parliamentary democracy. The rationalist perspective of Scholasticism and the openness of the new generations of Christian authors towards foreign and classical sources were fundamental for the construction of the Modern State and its institutions (Gierke 1987: 61-67, 92). Additionally, the connection between the Jewish and Christian processes is highly probable, considering that they were simultaneously developed and there was a continuous intellectual and practical interaction between Christian and Jewish. It should neither be forgotten that the scholars from both religions shared sources and models, especially the Arab and RomanGreek works (Melamed 1993). Authors like Plato and Aristotle or al-Farabi and Avicenna were usual bibliographical references in all the treatises of that age.

However, whether a theoretical influence took place, it is difficult to assure. There are many historical (and even cultural) aspects that hinder intellectual reconstructions in this sense. In the Jewish case, for example, authors never used to cite Christian sources (excepting for apologetic purposes) and hardly ever quoted in Latin (Sirat 2001: 210). For its part, Western studies on political philosophy have systematically tended to ignore the Jewish contributions and have not considered the possibility of intellectual exchanges within this field (Waller 1989). Nevertheless, the 
majority of contemporary authors hold (sometimes with some chauvinist hints ${ }^{18}$ ) that there was a Jewish previous and independent political and juridical tradition. Generally, they do not reject the influence of Roman law, although many scholars consider that its presence was limited to precise terminology and definitions (Agus 1952: 159). In any case, it is undeniable that, during the Middle Ages, an important Halakhatic development with political vocation took place. The survival of the communities as social and economic entities, the preservation of their religious identity and the legitimacy of their governmental structures, relied on that (Mittleman 1996: 39-42).

Jewish political theories on the power of majority and on its legitimation to impose its decisions to the minority started to be developed some centuries before the drafting of the Agreements of Barcelona. The process was slow and scarcely uniform for European Judaism in general, and divergent opinions and interpretations between communities and generations were habitual. The reasons of this tortuous path can be found in the political and religious decentralization of Medieval Judaism, which made intellectual communication difficult. In this sense, each territory tended to develop its own legal school of Talmudic interpretation (Roth 1988; Sagi 1995). It should not be surprising, considering that the evolution of the Western conception of democracy took more than 2,500 years. The doctrinal development of the Halakha was needed in order to provide real power to administrative institutions, especially when they were managed under the rule of majority, as in Catalonia.

Notwithstanding the undeniable existence and development of Jewish political and legal traditions, it would not be correct to think that this progress was alien to external theories. Social, judicial and economic interactions between Christian and Jews preclude this alleged isolation and self-sufficiency. In the case of the Crown of Aragon, Christian and Jewish political organization belonged to two different systems that coexisted in a same legal ecosystem framed under the supreme authority of the monarch.

In the 13th and 14th c., the reception of the ius commune and the legal innovations coming from Bologna had spurred the progressive and still distant construction of a ius proprium capable of replacing High-Medieval theocentrism by a iuscentric model ${ }^{19}$. Legal evolution was not uniform in the whole Crown, but the process appeared to be irreversible. The compilation of Catalan customs in the Usatges de Barcelona (12th c.), the grant of the Furs of Aragón (1247) and their confirmation and enlargement in the General Privilege (1283), the Furs de Valencia (1261) and the Leges Palatinae (1337) were some of the most important steps achieved in this process. Besides, the instauration of a proto-parliamentary system with whom the king had to agree part of his legislative activity was one of the main characteristics of Catalan-Aragonese politics. In that sense, Victor Ferro defined it as "a hierarchical set of general and particular rules which had acquired the rank of contract by virtue of the monarchs' inaugural oath and the solemn confirmations agreed in the Corts" (Ferro 2015: 320) ${ }^{20}$.

\footnotetext{
${ }^{18}$ Some authors have noted this problem and have tried to offer more objective, and less romantic, approaches. See, for example, Sicker (1993).

${ }^{19}$ De Montagut (2005: 191; 2010). For a theological perspective, see Kantorowicz (2016).

20 "[El sistema jurídic de Catalunya era] un conjunt jerarquitzat de normes generals $i$ particulars que en virtut del jurament inaugural dels monarques i de les solemnes confirmacions fetes en corts havien adquirit totes elles la categoria de contracte" (our own translation).
} 
The Jewish legal system was millenary. It was a perfectly organized legal system, with a complex hierarchy of sources with the written and oral Torah at the top. Its foundation and insand-outs were based on different sources, hermeneutical approaches and experiences. However, the diaspora forced the People of Israel to develop political theories capable of dealing with their position as a margined and non-sovereign minority. In this sense, the enforcement of Jewish models of authority was limited by this reality. Some of the most important aspects of communal self-government and organization were transpositions of royal decrees and privileges. Jewish autonomy never went so far. Therefore, the evolution of Jewish political traditions cannot be addressed from the romantic prism of intellectual self-sufficiency. The greatest role played by Catalan-Aragonese Jewish scholars was the harmonization between royal impositions and the Hala$k h a$. This effort permitted the progress of Jewish political thought.

Perhaps, an example would clarify it. At the end of the 13th Century, the Catalan aljamas enforced a deep reform of their institutions and mechanism of self-government. These reforms led to a "democratization" of the aljamas, which allowed the political participation of all the communal strata. This idea has captivated a wide range of historians, who have seen in the Catalan communities a clear example of Jewish democracy (for example, Epstein 1968). One of the milestones of this evolution took place in 1327, when the community of Barcelona enacted a taqqanah reforming the ruling institutions of the aljama ${ }^{21}$. The main objective of the ordinance was to prevent undue monopolizations of power and corruption. Among the measures of this taqqanah, it was decided to confer greater powers and a greater degree of institutionalization to the communal assembly. This assembly was known as the "Council of the Thirty", in reference to the number of members. For Daniel Elazar and Stuart Cohen, this reform aimed to recover the traditional Jewish assemblies ('edah) (Elazar and Cohen 1984: 163ff). However, it cannot be a coincidence that this institution coexisted with the "Council of the Hundred" (Consell de Cent), the ruling institution of Barcelona, whose attributions were almost the same.

It is true that some Medieval scholars attempted to inforce models of representativeness, like Maimonides - a gerontocracy largely based on Plato's republic (Melamed 1993) — or Rabbenu Tam-unanimity (Finkelstein 1924). However, those theories just aimed to replace the void authority that followed the end of kingship. The Catalan intellectual Nissim Gerondi expressed brightly that problem in his Darashah (religious sermon) n. 11, in which he noted the difference between the ideal government of the Torah and the real necessity to develop models of communal authority $^{22}$. Although it is impossible to speak about an isolated Jewish political tradition, Jewish communities reached certain harmony in dealing with external interferences and the Halakha, which enriched their political approaches. In that sense, the Agreements of 1354 are a window from which researchers can unravel this tangle of ideas, interactions and progresses.

\footnotetext{
${ }^{21}$ ACA, reg. 230, f. 106-107v [Baer (1929: doc. 189)].

${ }^{22}$ An online version is published in https://www.sefaria.org/Darashos_HaRan?lang=bi [15 August 2019]. See also the analysis by Professor Menachem Lorberbaum (2001).
} 


\section{CONCLUSIONS}

In the fourteenth century Catalonia endured a significant amount of political and economic hardships as well as natural disasters. A devastating plague, the Black Death, overcame Catalan territories causing thousands of deaths. To top it off, the already impoverished population had to withstand an increase of fiscal pressure as a consequence of the toll this context had taken on the king Pere el Cerimoniós' reign. The wars and conflicts that he had had to deal with caused an erosion of the economy and in terms of human lives without parallel since the Catalan counties and the Kingdom of Aragon had been united. Nevertheless, despite this general exhaustion affecting society as a whole, the impact that it had on the Jewish population specifically went even deeper. In addition to their precarious social and political position in Western Europe since the dawn of Middle Ages and its progressive worsening, they now had to undergo the prejudice and wrath of the people and some sectors of the clergy. Assaults, forced conversions, murders, kidnappings and extortions became commonplace. Also, the aljamas were immersed in internal power struggles and divisions.

In order to guarantee the survival of the communities in the midst of such mayhem, it became necessary to articulate a legal and politically responsible means. If it was to be effective at all it would have to be a joint effort with the explicit consent of the lay and ecclesiastical powers of the time. These were the premises that motivated the appearance of the Haskamot of Barcelona in 1354. They were specific agreements which attempted to achieve complete unity for the aljamas of the Crown through the creation of a confederation in which the entire Jewry would have been represented by delegates and whose attributions and duties would have been widely regulated. Their objective was to get the king and the pope to issue a number of measures which would put an end to the popular violence against the Jews, to reduce fiscal pressure and to increase their self-government on the basis of unity.

We know today the Haskamot project eventually failed. Notwithstanding, the document is still interesting for legal historiography. The measures proposed in the text shed some light on the ins-and-outs of the complex legal and jurisdictional relations between royal and communal institutions. Moreover, they evince the parallel development of both political and legal traditions. However, if we want to offer conclusive results the innumerable problems involved in seeking a theoretical common ground among both traditions are almost insurmountable. In that regard, the Agreements of 1354 are a perfect starting point for a comparative study on the development and interrelation between these two systems.

\section{REFERENCES}

\section{Primary Sources}

Assis, Y. T and Mañé, M ${ }^{a}$ C. and Escribà, G. 1993. Sources for the History of the Jews in the Crown of Aragón. Regesta of the Cartas Reales in the Archivo de la Corona de Aragón. Jerusalem: The Hank Schussheim Memorial Series.

Baer, F. 1929. Die Juden im Christlichen Spanien. Berlin: Akademie Verlag. 
Finkelstein, L. 1924. Jewish Self-Government in the Middle Ages. New York: The Jewish Theological Seminary of America.

Muntané i Santiveri J.X. 2006. Fonts per a l'estudi de l'aljama jueva de Tàrrega. Barcelona: PPU.

Nissim of Girona. Darashos ha-Ran in Sefaria https://www.sefaria.org/Darashos_HaRan?lang=bi

Sánchez Martínez, M. and Orti Gost, P. (editors). 1997. Textos jurídics catalans (Lleis i costums II/4). Corts, parlaments i fiscalitat a Catalunya: els capítols del donatiu (1288-1384). Barcelona: Generalitat de Catalunya (Departament de Justicia).

Schorr, Y. H. 1852. "On the Agreement that Came from the Communities of Spain in the year 1354, with an Introduction and Testimony. Ha-halutz, 1: 20-35" [In Hebrew].

\section{Bibliography}

AAVV. 1991. Les corts a Catalunya. Actes del Congrés d'Història institucional (28, 29 i 30 d'abril de 1988). Barcelona: Generalitat de Catalunya, Departament de Cultura.

Alsina, T. and Feliu, E. 1995. "Mossé Natan, poeta hebreu de Tàrrega". In Constitució de l'Associació d'Estudiosos del Judaisme Català a Tàrrega. Tàrrega: Museu Comarcal, pp. 1148.

Agus, I. A. 1952. "Democracy in the Communities in the Early Middle Ages". The Jewish Quarterly Review, 43 (2): 153-176.

Assis, Y. T. 1996-1997. “Jaime II y los judíos en la corona de Aragón”. Anales de la Universidad de Alicante. Historia Medieval, 11: 331-342.

Assis, Y. T. 1997. Jewish Economy in the Medieval Crown of Aragon. Money and Power. Leiden: Brill.

Baer, Y. 1965. Studien zur Geschichte der Juden im Königreich Aragonien. Vaduz: Kraus Reprint.

Baer, Y. 1989. "The Origins of Jewish Communal Organization in the Middle Ages". In Binah: Studies in Jewish History, Vol. 1. Ed. Joseph Dan. New York: Praeger, pp. 59-82.

Baer, Y. 2001. A History of the Jews in Christian Spain. Skokie (Illinois): Varda Books.

Baron, S. W. 1976. "The Jewish Factor in Medieval Civilization" [ original in 1942] In. Medieval Jewish Life: Studies from the Proceedings of the American Academy for Jewish Research. Ed. Robert Chazan. New York: KTAV Publishing House, Inc., pp. 3-50.

Bisson, T. N. 1986. The Medieval Crown of Aragon. Oxford: Oxford University Press.

Chazan, R. 2006. The Jews of Medieval Christendom, 1000-1500. New York: Cambridge University press.

Cohen, J. 1983. The Friars and the Jews. Ithaca (NY) and London: Cornell University Press.

Cohen Jr., S. K. 2007. "The Black Death and the Burning of Jews". Past and Present, 196: 3-36.

D’Abadal, R. 1987. Pere el Cerimoniós i els inicis de la decadència política a Catalunya. Barcelona, Edicions 62. 
Dorff, E. N. and Rosett, A. 1988. A Living Tree. The Roots and Growth of Jewish Law. Albany: State University of New York Press.

Elazar, D. J. and Cohen, S. 1984. The Jewish Polity: Jewish Political Organization from Biblical Times to the Present. Bloomington: Indiana University Press.

Elazar, D. J. 1997. "The kahal”. In Kinship and Consent: The Jewish Political Tradition and its Contemporary Uses. Ed. Daniel J. Elazar. New Brunswick: Transaction Publishers, pp. 233276.

Elon, M. "The Contribution of Spanish Jewry to the World of Jewish Law". Jewish Political Studies Review, 5, vol. 3/4 (1993): 35-54.

Epstein, I. 1968. The "Responsa" of Rabbi Solomon ben Adreth of Barcelona (1235-1310) as a Source of the History of Spain. New York: Ktav Publishing House.

Feliu, E. and Riera, J. 1987. "Els acords de Barcelona de 1354”. Calls, 2:145-179.

Feliu, G. 1999. “La demografía baixmedieval catalana: estat de la qüestió i propostes de futur”. Revista d'Història Medieval, 10: 13-43Ferrer i Mallol, Mª T. 1970-1971.

Ferrer i Mallol, $\mathrm{M}^{\mathrm{a}}$.T.1970. "El patrimoni reial i la recuperació dels senyorius jurisdiccionals en els Estats catalano-aragonesos a la fi del segle XIV”. Anuario de Estudios Medievales, 7: 351491.

Ferro, V. 2015. El dret públic català. Les institucions a Catalunya fins al Decret de Nova Planta. Barcelona: Societat Catalana d'Estudis Jurídics.

Freedman, P. 1991. The Origins of Peasant Servitude in Medieval Catalonia. Cambridge: Cambridge University Press.

Gierke, O. 1987. Political Theories of the Middle Age. Cambridge: Cambridge University Press.

Grayzel, S. 1933. The Church and the Jews in the XIIIth Century. Philadelphia: The Dropsie College for Hebrew and Cognate Learning.

Horrox, R. 1994. The Black Death. New York: Manchester University Press.

Jacobs L. 1995. The Jewish Religion, a Companion. New York, Oxford University Press.

Kantorowicz, E. H. 2016. The King's Two Bodies: A Study in Medieval Political Theology. Princeton: Princeton University Press.

Lorberbaum, M. 2001. Politics and the Limits of Law: Secularizing the Political in Medieval Jewish Thought. Stanford: University of Stanford Press.

Lyons W. L. 2010. A History of Modern Scholarship on the Biblical Word Herem. Lewiston (NY): The Edwin Mellen Press.

McMichael, S. J. and Myers, S. E. 2004. Friars and Jews in the Middle Ages and Renaissance, Vol. II. Leiden: Brill.

Melamed, A. 1993. "The Attitude towards Democracy in Medieval Jewish Philosophy". Jewish Political Studies Review, 5 (1/2): 33-56.

Mittleman, A. L. 1996. The Politics of the Torah. The Jewish Political Tradition and the Founding of Agudat Israel. Albany: State of New York University Press. 
De Montagut, T. 2010. “La noció erudita de justicia a la Corona d'Aragó (S. XIII-XVIII)”. Revista d'etnologia de Catalunya, 35: 88-97.

Montoro, J. 2018. "Mesurar la mortalitat a Catalunya (s. XIII-XIV). Estat de la qüestió, metodologia i fonts". In Investigar l'Edat Mitjana. Eds., Flocel Sabaté i Curull and Jesús Brufal Sucarrat. Lleida: Pagès Editors, pp.67-84.

Muntané i Santiveri, J. X. 2012. "Aproximació a les causes de l'avalot de Tàrrega de 1348”. Tamid, 8: 103-129.

Niremberg, D. 1996. Communities of Violence. Persecution of Minorities in the Middle Ages. Princeton: Princeton University Press.

Neuman, A. A. 1944. The Jews in Spain. Their Social, Political and Cultural Life during the Middle Ages. Philadelphia: the Jewish Publication Society of America.

Ortí i Gost, P. 1999. "Una primera aproximació als fogatges catalans de la dècada de 1360”. Anuario de Estudios Medievales, 29: 747-773.

Parrilla Valero, F. 2019. "La Pesta Negra del 1348 a la Corona d'Aragó. Una revolució social, econòmica i salubrista". Gimbernat. 71: 13-22.

Pere el Cerimoniós. 1983. "Crònica". In Les quatre grans cròniques. Ed. Ferran Soldevilla. Barcelona: Editorial Selecta, pp. 1001-1225

Pieters, B. 2006. De Akkorden van Barcelona (1354). Historische en Kritische analyse. Barcelona, PPU.

Pladevall, A. 1962. "La disminució de poblament a la Plana de Vich a mitjans del segle XIV". Ausa, 44: 361-373.

Postan, M. M. and Miller, E. 1987. The Cambridge Economic History of Europe, II. Cambridge: Cambridge University Press.

Rabinowitz, L. 1938. "The Talmudic Basis of the Herem Ha-Yishub". The Jewish Quarterly Review, 28 (3): 217-223.

Ray, J. 2012. The Jew in Medieval Iberia, 1100-1500. Boston: Academic Studies Press.

Riera, J. 2018. "La protecció, un impost sobre les aljames dels jueus reials". In Renda Feudal $i$ fiscalitat a la Catalunya baixmedieval: estudis dedicats Manuel Sánchez Martínez. Eds. Pere Ortí Gost and Pere Verdés Pijuan. Barcelona: CSIC, pp. 95-142.

Roth, J. I. 1988. "The Justification for Controversy under Jewish Law". California Law Review, 76 (2): 337-387.

Sagi, A. 1995. "Models of Authority and the Duty of Obedience in Halakhic Literature". AJS Review 20 (1): 1-24.

Sánchez-Arcilla, J. 2005. Historia del derecho español. Barcelona: Cálamo.

Shapira, H. 2014. "The Right to Political Participation in Jewish Tradition: Contribution and Challenges". In Religion and the Discourse of Human Rights. Eds. Hanoch Dagan, Shahar Lifshitz, and Yedidia Z. Stern. Jerusalem: Israel Democracy Institute, pp. 266-296.

Shetreet, S. and Homolka, W. 2017. Jewish and Israeli Law- an Introduction. Berlin: De Gruyter. 
Sicker, M. 1993. "Democracy and Judaism: The Question of Equality". Jewish Political Studies Review, 5 (1/2): 57-78.

Sirat, C. 2001. "Biblical commentaries and Christian influence: the case of Gersonides" In $\mathrm{He}$ brew Scholarship and the Medieval World. Ed. Nicholas de Lange. Cambridge: Cambridge University Press, pp. 210-223.

Smith, R. S. 1944. "Fourteenth-Century Population Records of Catalonia". Speculum, 19 (4): 494-501.

Tartakoff, P. 2012. Between Christian and Jew. Conversion and Inquisition in the Crown of Aragon, 1250-1391. Philadelphia: University of Pennsylvania Press.

Waller, H. M. 1989. "Political Philosophy and the Jewish Political Tradition: Can they be integrated?". Jewish Political Studies Review, 1 (3/4, Jewish Political Studies in the University): 43-57. 